\title{
JUURNAL.RU
}

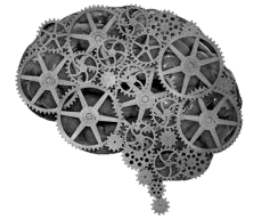

COMPANY GROUP "INTELLEKT"

\author{
Чурилова С.В. \\ Оренбургский государственный университет \\ Оренбург, Россия
}

doi: 10.18411/lj2016-5-5-15

\section{Карантинный фитосанитарный контроль в Российской Федерации: проблемы и перспективы развития}

В настоящее время неравномерное экономическое развитие стран и международное разделение труда привели к тому, что изолированное развитие государства только за счет имеющихся у него ресурсов не представляется возможным. Поэтому на современном этапе развития общества экономика вышла за пределы территориальных границ отдельных государств, приобрела интернациональный характер, что привело к увеличению объёмов и расширению географии международных торговых обменов. Активное развитие международных торговых отношений, безусловно, способствует росту ВВП, развитию отраслей производства, улучшению благосостояния населения, но, к сожалению, процессы экономической интернационализации, международной интеграции имеют и негативные последствия, среди которых необходимо отметить возрастание угрозы ввоза и распространения карантинных вредных организмов, которые наносят огромный экономический и экологический ущерб сельскому и лесному хозяйству страны - импортёра. Согласно данным Продовольственной сельскохозяйственной организации ООН (FAO), несмотря на предпринимаемые человечеством меры по защите урожая сельскохозяйственной продукции от вредителей и сорняков, его ежегодные потери достигают 30 [1]. 
Сегодня экономика России стала неотъемлемой частью мировой экономической системы. В настоящее время в Россию ежегодно ввозится 15 - 28 млн.тонн подкарантинной растительной продукции, до 600 млн. штук посадочного материала из 40 стран мира, во многих из которых распространены вредные организмы и сорняки, имеющие карантинное значение для России, например: картофельная моль, кукурузный жук диабротика, филлоксера винограда капровый жук, амброзия, ценхрус многоцветковый, горчак розовый и другие [2]. Потери Российской Федерации, наносимые ежегодно вредными организмами урожаю сельскохозяйственной продукции, исчисляются несколькими десятками миллионов тонн условных зерновых единиц, а в денежном выражении составляют сотни миллиардов рублей. Наносимый вредителями и болезнями ущерб лесам России реально в нашей стране не учтен.

Ещё в 30 - е годы XX века академик Н.И. Вавилов писал: «Развертывание широкой интродукции ... растений и сортов должно идти одновременно с созданием карантина растений. Организация карантинной инспекции составляет непременную составную часть интродукции растений. Ввоз растений из - за границы должен быть строго контролируем» [3].

В настоящее время одной из приоритетных задач, стоящих перед Российской Федерацией и другими членами ЕАЭС является гибкое, грамотное и эффективное применение фитосанитарных мер, как инструмента нетарифного регулирования ВЭД, с целью недопущения интродукции карантинных вредных организмов на свои территории.

Однако «Сегодня, в эпоху глобализации, задача по предотвращению распространения насекомых - вредителей и заболеваний растений, не препятствуя при этом международной торговли, а, наоборот, наращивая ее объемы, становится сложнее и важнее чем когда-либо» - сказал Генеральный директор ФАО Жозе Грациану да Силва в своём выступлении, посвященном программе «Нулевой голод» в Азиатско - Тихоокеанском регионе 14 мая 2013г. [1]. 
Усиление значения фитосанитарного контроля при осуществлении ВЭД выявило проблемы в этой сфере и обозначило перспективы её развития.

Одним из главных препятствий для эффективного и всестороннего осуществления фитосанитарного контроля как на территории ЕАЭС, так и на таможенной и государственных границах стран - членов ЕАЭС (в том числе в Российской Федерации) является отсутствие единой окончательно сформированной, совершенной нормативно - правовой базы в области фитосанитарной безопасности в ЕАЭС.

Первый шаг в направлении формирования единой нормативно - правовой базы фитосанитарных мер был сделан 25 января 2008 года, когда было принято Соглашение ЕврАзЭС о проведении согласованной политики в области технического регулирования, санитарных и фитосанитарных мер, предусматривающее разработку и применение единой системы технических регламентов ЕврАзЭС. Однако эта система так и не была разработана [3]. В дальнейшем в рамках исполнения Решения Комиссии ТС от 20 сентября 2010 года № 406 был подготовлен проект «Стратегии развития единой системы технического регулирования, применения СФС ТС на 2011 - 2015 годы», который не был ратифицирован.

Принятый 29 мая 2014 года Договор о ЕАЭС установил лишь общие правила применения санитарных и фитосанитарных мер и технического регулирования в ЕАЭС. Для их конкретизации Совет ЕЭК в Решении № 58 от 16 июля 2014 года запланировал до 31 декабря 2015 года разработать следующие документы:

- Международный договор ЕАЭС О принципах и подходах к гармонизации законодательства в сфере государственного контроля (надзора) за соблюдением требований технических регламентов ЕАЭС;

- Международный договор ЕАЭС О порядке и условиях устранения технических барьеров во взаимной торговле с третьими странами; 
- Единый перечень карантинных объектов ЕАЭС;

- Единые карантинные фитосанитарные требования ЕАЭС.

Но рабочая группа по подготовке международных договоров была сформирована распоряжением Коллегии ЕЭК № 79 лишь 18 августа 2015 года и к 1 января 2016 года состоялось только одно заседание рабочей группы. Предложения по проектам международных договоров до настоящего времени не поступили от Республики Армения и Российской Федерации. Вопрос о Едином перечне карантинных объектов ЕАЭС был рассмотрен на заседании Коллегии ЕЭК 1 сентября 2015 года, но решение до сих пор не принято. Проект Единых карантинных фитосанитарных требований был размещён для публичного обсуждения с 26.08 до 02.11.2015 г. на правовом портале ЕАЭС. В настоящее время он находится на стадии доработки.

На стадии доработки находятся и Единые правила и нормы обеспечения карантина растений ЕАЭС, а Порядок взаимодействия уполномоченных органов государств - членов ЕАЭС при введении временных карантинных фитосанитарных мер и Порядок лабораторного обеспечения карантинных фитосанитарных мер проходят правовую экспертизу.

Заключение вышеуказанных международных договоров и их ратификация, принятие Советом ЕЭК решений по вышеперечисленным вопросам позволят создать единую нормативно - правовую базу фитосанитарных мер ЕАЭС, обеспечивающую качественное проведение фитосанитарного контроля на таможенной и государственных границах стран - членов ЕАЭС.

Другим фактором, препятствующим эффективному проведению фитосанитарного контроля на таможенной и Государственной границах РФ, является отсутствие согласованности между нормативно - правовыми актами Российской Федерации и ЕАЭС (ТС) [4].

Так в Решении Комиссии Таможенного союза № 318 «Об обеспечении карантина растений в таможенном союзе» от 18.06.2010 г. (в ред. от 09.10.2014 г.) в пункте 4.1.4 указано, что, если должностным лицом уполномоченного 
органа устанавливается поддельность или недействительность фитосанитарного сертификата, то оно принимает решение о запрете ввоза партии подкарантинной продукции на территорию ЕАЭС, а в Постановлении Правительства РФ № 502 «Об утверждении правил осуществления государственного карантинного фитосанитарного контроля в пунктах пропуска через государственную границу Российской Федерации» от 29.06.2011 г. (в ред. от 23.04.2012 г.) в пункте 14 в аналогичной ситуации должностное лицо должно принять решение о направлении подкарантинной продукции для проведения досмотра товаров должностными лицами Федеральной службы по ветеринарному и фитосанитарному надзору или ее территориальных органов.

Гармонизация нормативно - правовой базы фитосанитарных мер Российской Федерации и ЕАЭС является перспективным направлением совершенствования фитосанитарного контроля.

Одной из проблем в сфере обеспечения безопасности, защиты и сохранения сельскохозяйственной продукции от ввозимых вредных организмов является ненадлежащее состояние законодательства Российской Федерации, устанавливающего правовую ответственность в данной сфере.

Согласно закону Канады «О защите растений» за нарушение правил и норм обеспечения карантина растений установлен штраф до 250 тыс. долларов, в отдельных случаях - до шести месяцев лишения свободы. За наиболее грубые, сознательно совершенные нарушения предусмотрена ответственность в виде лишения свободы до двух лет [2].

В то же время в Российской Федерации административная ответственность за нарушения в области карантина растений незначительна (установлен штраф для физических лиц - до 5 тыс. руб., для юридических лиц до 10 тыс. руб.), а уголовная ответственность устанавливается только за те нарушения, которые влекут за собой тяжкие последствия (порча или уничтожение семенного фонда, полная или частичная гибель урожая, 
причинение вреда здоровью человека и т.д.). В этом случае назначается максимальное наказание в виде ограничения свободы до 2 лет [5].

Достаточно мягкое наказание за нарушение фитосанитарных норм и правил способствует сохранению высокого уровня правонарушений в этой области, поэтому в России необходимо ужесточить ответственность физических, юридических и должностных лиц за невыполнение карантинных фитосанитарных требований.

Глобальное потепление климата, повлекшее за собой изменение ареалов распространения насекомых - вредителей, растений - сорняков и возбудителей заболеваний растений и появление новых более вирулентных и агрессивных штаммов и рас известных патогенов (высоко патогенная раса стеблевой ржавчины пшеницы (Ug 99)), а также вступление в ВТО, которая требует единообразного подхода к оценке импортной и местной продукции с целью недопущения произвольной и неоправданной дискриминации, a, следовательно, применение унифицированного оборудования и методов, соответствующих мировым стандартам - два фактора, которые предопределили дальнейшее развития и совершенствование фитосанитарного контроля в направлении создания широкой сети высокооснащённых лабораторий, использующих современные методы диагностики.

Если раньше лаборатории Россельхознадзора использовали только бактериоскопические и бактериологические методы, основанные на изучении морфологических и анатомических признаков с применением техники микроскопирования, то в настоящее время они активно внедряют различные серологические (иммуноферментный и иммунофлюоресцентный) и молекулярные (ПЦР - диагностика) методы, которые являются основой международных диагностических протоколов.

Вопросами совершенствования лабораторной карантинной фитосанитарной диагностики стандартизации методик и создания гармонизированных диагностических процедур, которыми могли бы 
пользоваться разные лаборатории, работающие в этой области в Российской Федерации занимается ФГБУ «ВНИИКР». Оно проводит оптимизацию существующих методов и разрабатывает новые методы выявления патогенов растений в подкарантинных материалах и их видовой идентификации, а также дублирующие методы, использующиеся для подтверждения результатов экспертизы.

В настоящее время в ФГБУ «ВНИИКР» и его семи филиалах в разных регионах России внедрены такие новые методы лабораторной диагностики как флэш-ПЦР (специфическая флуоресцентная гибридизация в процессе амплификации), метод рестрикционного анализа продуктов амплификации, метод иммуноспецифической ПЦР [6].

Развитие лабораторной карантинной фитосанитарной диагностики позволит вывести её на более высокий качественный уровень, соответствующий мировым стандартам.

Достижение данной цели существенно затрудняют недостаток финансирования и нехватка высококвалифицированных кадров.

Эти проблемы актуальны для всей сферы фитосанитарного контроля. Ежегодно сокращается подготовка специалистов по фитосанитарии. В РГАУMCXА, Санкт - Петербургском, Кубанском, Новосибирском государственных аграрных университетах ликвидированы факультеты защиты растений или сокращены профильные кафедры [2].

В то же время в целях обеспечения стабильности и результативности фитосанитарного контроля в пунктах пропуска через таможенную границу ЕАЭС и Государственную границу РФ в настоящее время существует необходимость специализации и повышения квалификации специалистов таможенного дела в фитосанитарной области. Студенты, обучающиеся по специальности «таможенное дело» должны иметь практические занятия в экспертных лабораториях и проходить практику в организациях, осуществляющих фитосанитарные экспертизы. 
Таким образом, подводя итог вышесказанному, хотелось бы еще раз подчеркнуть, что, несмотря на имеющиеся проблемы в сфере карантинного фитосанитарного контроля, он, как метод нетарифного регулирования, является эффективным инструментом протекционистской политики в руках государства в сфере ВЭД, так как, защищая территорию государства от проникновения карантинных вредных организмов и сорняков, обеспечивает экологическую и экономическую безопасность страны.

Необходимо отметить, что в условиях современного мирового экономического кризиса, санкционной войны между Западом и Россией, возрастающей угрозы международного биотерроризма, меры карантинного фитосанитарного контроля становятся политическим оружием, обеспечивающим национальную безопасности Российской Федерации.

В свете современных реалий перед Таможенной службой РФ и Федеральной службой по карантинному и фитосанитарному надзору РФ ставится задача повышения эффективности и качества осуществления государственного карантинного фитосанитарного контроля на таможенной границе ЕАЭС и Государственной границе РФ с целью обеспечения национальных интересов страны. 


\section{Литература:}

1. Ерохин С.3. Анализ этапов постиндустриальной трансформации // Новая экономика: монография [Текст] / под ред. Е.Ф.Авдошкина, В.С.Сизова; ВСЭИ. - М.: Магистр, 2009. - С.72-90.

2. Рынок труда, занятость и заработная плата [Электронный ресурс] - URL: http://www.pocстат.ru.

3. Стратегия национальной безопасности России до 2020 года [Электронный pecypc] - URL: http://www.scrf.gov.ru.

4. Трансформация государственной собственности в условиях смешанной экономики [Текст] /отв. ред. А.Г.Зельднер, И.Ю.Ваславская; Ин-т экономики РАН. - М: Наука, 2006. - 261 с.

5. Чайка Ю. Доклад о результатах проверки госкорпораций: [Электронный pecypc]. - Режим доступа: http://www.vedomosti.ru.

6. Чилимова Т.А. К вопросу об участии государства в системе корпоративного управления [Текс]//Управленец. - №9-10 (38). - С.18-21. 